\title{
Optimization Methods Applied to Power Systems
}

\author{
Francisco G. Montoya *®D, Raúl Baños ${ }^{(}$, Alfredo Alcayde $(\mathbb{D}$ and Francisco Manzano-Agugliaro $(\mathbb{D}$ \\ Department of Engineering, University of Almeria, ceiA3, 04120 Almeria, Spain; rbanos@ual.es (R.B.); \\ aalcayde@ual.es (A.A.); fmanzano@ual.es (F.M.-A.) \\ * Correspondence: pagilm@ual.es; Tel.: +34-950-015791; Fax: +34-950-015491
}

Received: 6 May 2019; Accepted: 13 June 2019; Published: 17 June 2019

check for updates

\section{Introduction}

Continuous advances in computer hardware and software are enabling researchers to address optimization solutions using computational resources, as can be seen in the large number of optimization approaches that have been applied to the energy field.

Power systems are made up of extensive complex networks governed by physical laws in which unexpected and uncontrolled events can occur. This complexity has increased considerably in recent years due to the increase in distributed generation associated with increased generation capacity from renewable energy sources. Therefore, the analysis, design, and operation of current and future electrical systems require an efficient approach to different problems (like load flow, parameters and position finding, filter design, fault location, contingency analysis, system restoration after blackout, islanding detection of distributed generation, economic dispatch, unit commitment, etc.). Given the complexity of these problems, the efficient management of electrical systems requires the application of advanced optimization methods that take advantage of high-performance computer clusters.

This special issue belongs to the section "Electrical Power and Energy System". The topics of interest in this special issue include different optimization methods applied to any field related to power systems, such as conventional and renewable energy generation, distributed generation, transport and distribution of electrical energy, electrical machines and power electronics, intelligent systems, advances in electric mobility, etc. The optimization methods of interest for publication include, but are not limited to:

- $\quad$ Expert Systems

- Artificial Neural Networks

- Fuzzy Logic

- Genetic Algorithms

- Evolutionary Algorithms

- Simulated Annealing

- Tabu Search

- Ant Colony Optimization

- Particle Swarm Optimization

- Multi-Objective Optimization

- Parallel Computing

- Linear and Nonlinear Programming

- Integer and Mixed-Integer Programming

- Dynamic Programming

- Interior Point Methods

- Lagrangian Relaxation and Benders Decomposition-Based Methods

- General Stochastic Techniques. 


\section{Statistics of the Special Issue}

The statistics of the call for papers for this special issue related to published or rejected items were: Total submissions (113), published $(36 ; 31.8 \%)$, and rejected $(77 ; 68.3 \%)$.

The authors' geographical distribution by countries for published papers is shown in Table 1 , where it is possible to observe 144 authors from 19 different countries. Note that it is usual for an article to be signed by more than one author, and for authors to collaborate with others of different affiliation.

Table 1. Geographic distribution by countries of authors.

\begin{tabular}{cc}
\hline Country & Number of Authors \\
\hline China & 80 \\
Spain & 11 \\
South Korea & 9 \\
Cameroon & 5 \\
Malaysia & 5 \\
United States & 5 \\
Taiwan & 4 \\
Thailand & 4 \\
Viet Nam & 4 \\
Brazil & 3 \\
Egypt & 3 \\
Algeria & 2 \\
France & 2 \\
Russian Federation & 2 \\
Chile & 1 \\
Germany & 1 \\
Mexico & 1 \\
New Zealand & 1 \\
Singapore & 1 \\
\hline Total & $\mathbf{1 4 4}$ \\
\hline
\end{tabular}

\section{Authors of this Special Issue}

The authors of this special issue and their main bibliometric indicators are summarized in Table 2, where they have been ordered from the highest to the lowest $\mathrm{H}$-index. The novel authors, those considered with an $\mathrm{H}$-index equal to zero are 29, and those of $\mathrm{H}$-index equal to 1 are 27 . On the other hand, the internationally recognized authors, those considered with an H-index of 10 or higher, are 31 . It is remarkable that these authors (H-index $\geq 10$ ), on average, have more than 123 co-authors, more than 110 documents published, and more than 1069 citations.

Table 2. Affiliations and bibliometric indicators for the authors.

\begin{tabular}{ll}
\hline Author & Affiliation \\
\hline Jurado F. & Universidad de Jaen \\
Watson N. & University of Canterbury \\
Trentesaux D. & University of Valenciennes et du Hainaut-Cambresis \\
Liu N. & North China Electric Power University \\
Premrudeepreechacharn S. & Chiang Mai University \\
Sun Y. & Hohai University \\
Gu W. & Southeast University \\
Aguado, J.A. & Universidad de Málaga \\
Baños R. & Universidad de Almeria \\
Montoya F. & Universidad de Almeria \\
Maciel P. & Universidade Federal de Pernambuco \\
Liu M. & South China University of Technology \\
Zhang C. & Shandong University \\
Liu Z. & North China Electric Power University \\
\hline
\end{tabular}


Table 2. Cont.

\begin{tabular}{|c|c|}
\hline Author & Affiliation \\
\hline Wu Z. & Southeast University \\
\hline Miao S. & Huazhong University of Science and Technology \\
\hline Yu J. & Chongqing University \\
\hline Ferreira J. & Universidade de Pernambuco \\
\hline Won D. & Inha University, Incheon \\
\hline Bai L. & The University of North Carolina at Charlotte \\
\hline $\mathrm{Hu}$ Y. & Hohai University \\
\hline Yao L. & National Taipei University of Technology \\
\hline Lim W. & UCSI University \\
\hline Yang F. & Chongqing University \\
\hline Sun $\mathrm{H}$. & Hebei University of Technology \\
\hline Callou G. & Universidade Federal Rural de Pernambuco \\
\hline Lee J. & University of Louisiana at Lafayette \\
\hline Zhao D. & North China Electric Power University \\
\hline Zhang X. & Shantou University \\
\hline Li Y. & Zhejiang University City College \\
\hline Gutiérrez-Alcaraz G. & Tecnológico Nacional de México / I.T. \\
\hline Huang N. & Northeast Electric Power University \\
\hline Xiang J. & Zhejiang University \\
\hline Morshed M. & University of Louisiana at Lafayette \\
\hline Sun B. & Shandong University \\
\hline Bekrar A. & University of Valenciennes et du Hainaut-Cambresis \\
\hline Rhee S. & Yeungnam University \\
\hline Kamel S. & Aswan University \\
\hline Xie M. & South China University of Technology \\
\hline Tutsch D. & Bergische Universitat Wuppertal \\
\hline Sidorov D. & $\begin{array}{l}\text { Melentiev Energy Systems Institute of Siberian Branch of the Russian Academy } \\
\text { of Sciences }\end{array}$ \\
\hline Zhang X. & Nanyang Technological University \\
\hline Zhou B. & China Southern Power Grid \\
\hline Perng J. & National Sun Yat-Sen University Taiwan \\
\hline Panasetsky D. & $\begin{array}{l}\text { Melentiev Energy Systems Institute of Siberian Branch of the Russian Academy } \\
\text { of Sciences }\end{array}$ \\
\hline Zheng T. & Tsinghua University \\
\hline Li J. & Northeast China Institute of Electric Power Engineering \\
\hline Hinojosa V. & Universidad Técnica Federico Santa María \\
\hline Siritaratiwat A. & Khon Kaen University \\
\hline Hua D. & South China University of Technology \\
\hline Hamouda A. & Université Ferhat Abbas de Sétif \\
\hline Zhang L. & Tianjin University of Commerce \\
\hline Alcayde A. & Universidad de Almeria \\
\hline Ge W. & State Grid Liaoning Electric Power Supply Co., Ltd. \\
\hline Zhang L. & Chongqing University \\
\hline Zhang C. & Hunan University \\
\hline $\mathrm{Wu} \mathrm{J}$. & Beihang University \\
\hline Wang Y. & North China Electric Power University \\
\hline Febrero-Garrido L. & Defense University Center \\
\hline Chambers T. & University of Louisiana at Lafayette \\
\hline Truong A. & HCMC University of Technology and Education \\
\hline Nganhou J. & University of Yaoundé \\
\hline Li Y. & Huazhong University of Science and Technology \\
\hline Lin L. & Jilin Institute of Chemical Technology \\
\hline Jiang T. & North China Electric Power University \\
\hline Ebeed M. & Sohag University \\
\hline Chatthaworn R. & Khon Kaen University \\
\hline Duong T. & Industrial University of Ho Chi Minh City \\
\hline Hamandjoda O. & University of Yaoundé \\
\hline
\end{tabular}


Table 2. Cont.

\begin{tabular}{|c|c|}
\hline Author & Affiliation \\
\hline Chun Y. & Hongik University \\
\hline Ye C. & Huazhong University of Science and Technology \\
\hline Mei S. & Qinghai University \\
\hline Nguyen T. & Industrial University of Ho Chi Minh City \\
\hline Mao T. & China Southern Power Grid \\
\hline Wang Y. & Hohai University \\
\hline Arrabal-Campos F. & Universidad de Almeria \\
\hline Tiang S. & UCSI University \\
\hline Hmida J. & University of Louisiana at Lafayette \\
\hline Tan T. & UCSI University \\
\hline Chen S. & Anqing Teachers College \\
\hline Sahli Z. & Université Ferhat Abbas de Sétif \\
\hline Kim C. & Yeungnam University \\
\hline Li F. & Shandong University \\
\hline Meva'a L. & University of Yaoundé \\
\hline Wadood A. & Yeungnam University \\
\hline Le Y. & State Grid Zhejiang Electric Power Corporation \\
\hline Khunkitti S. & Khon Kaen University \\
\hline Hong Wong C. & UCSI University \\
\hline Shim M. & Inha University, Incheon \\
\hline Dong X. & North China Electric Power University \\
\hline Du Y. & State Grid Ganzhou Electric Power Supply Company \\
\hline Xie L. & China Electric Power Research Institute \\
\hline Li L. & Huazhong University of Science and Technology \\
\hline Du X. & Southeast University \\
\hline Fang C. & State Grid Shanghai Municipal Electric Power Company \\
\hline Ndzana B. & University of Yaoundé \\
\hline Yew Pang J. & Heriot-Watt University, Malaysia \\
\hline $\mathrm{Hu} \mathrm{Z}$. & Zhejiang Electric Power CorporationWenzhou Power Supply Company \\
\hline Chen Y. & Zhejiang University \\
\hline Liu J. & State Grid Shanghai Municipal Electric Power Company \\
\hline Xue L. & Northeast China Institute of Electric Power Engineering \\
\hline Yimen N. & University of Yaoundé \\
\hline Khurshiad T. & Yeungnam University \\
\hline Kim N. & Hyosung Group \\
\hline Shao B. & $\begin{array}{l}\text { State Grid Liaoning Electric Power Company Limited Electric Power } \\
\text { Research Institute }\end{array}$ \\
\hline Guo B. & Jilin University \\
\hline Li K. & Beihang University \\
\hline Kuang J. & Shandong University \\
\hline $\mathrm{Yu} \mathrm{J}$. & Anyang Institute of Technology \\
\hline Sun J. & Beihang University \\
\hline Ling $P$. & State Grid Shanghai Municipal Electric Power Company \\
\hline Guo B. & North China Electric Power University \\
\hline Li C. & Huazhong University of Science and Technology \\
\hline Leiva, J & Universidad de Malaga \\
\hline $\mathrm{Li} \mathrm{J.}$ & Electric Power Research Institute of State Grid Liaoning Electric Power Co. Ltd. \\
\hline Kuo Y. & Taiwan Power Company \\
\hline Yang X. & Chongqing University \\
\hline Yu L. & Tianjin University of Commerce \\
\hline Zhang Y. & Zhoushan Power Company of State Grid \\
\hline Niu F. & Zhejiang University \\
\hline Ogando-Martínez A. & Universidad de Vigo \\
\hline Han X. & State Grid Sichuan Electric Power Company \\
\hline Ren X. & Tianjin University of Commerce \\
\hline Gan C. & Zhoushan Power Company of State Grid \\
\hline
\end{tabular}


Table 2. Cont.

\begin{tabular}{ll}
\hline Author & Affiliation \\
\hline Xiao L. & Tianjin University of Commerce \\
Fan C. & State Grid Sichuan Electric Power Research Institute \\
Ton T. & Thu Duc College of Technology \\
Zhang J. & Northeast Electric Power University \\
Chen H. & Tsinghua University \\
Zhou H. & Northeast Electric Power University \\
López-Gómez J. & Universidad de Vigo \\
Jiang S. & Anqing Teachers College \\
Lu S. & Taiwan Power Company \\
Sun G. & South China University of Technology \\
Cheng P. & Guangzhou Power Supply Bureau Co., Ltd. \\
Li X. & North China Electric Power University \\
Cheng W. & Shenzhen Power Supply Bureau Co., Ltd. \\
Cheng R. & Shenzhen Power Supply Bureau Co., Ltd. \\
Lee H. & Korea Electrotechnology Research Institute \\
Chen Z. & State Grid Sichuan Electric Power Research Institute \\
Shi J. & Shenzhen Power Supply Bureau Co., Ltd. \\
Abdo M. & Aswan University \\
Carmona R. & Universidad de Malaga \\
Wei W. & South China University of Technology \\
\hline
\end{tabular}

\section{Brief Overview of the Contributions to this Special Issue}

\subsection{Keyword Analysis}

The analysis of the keywords identifies or summarizes the work of the researchers. This section analyses the keywords obtained from the 36 manuscripts published in this special issue [1-36]. The keyword analysis of the papers of this special issue shows a wide variety of terms, reaching 135 different keywords. Figure 1 shows a cloud of words using author keywords. The most used and highlighted keywords are: Optimal power flow, genetic algorithm, optimization, particle swarm optimization, demand response, energy management, metaheuristic, and wind power. If we split the author keywords in simple words, it is possible to get Figure 2, where the highlighted words are now: Optimal, power, energy, system, and algorithm.

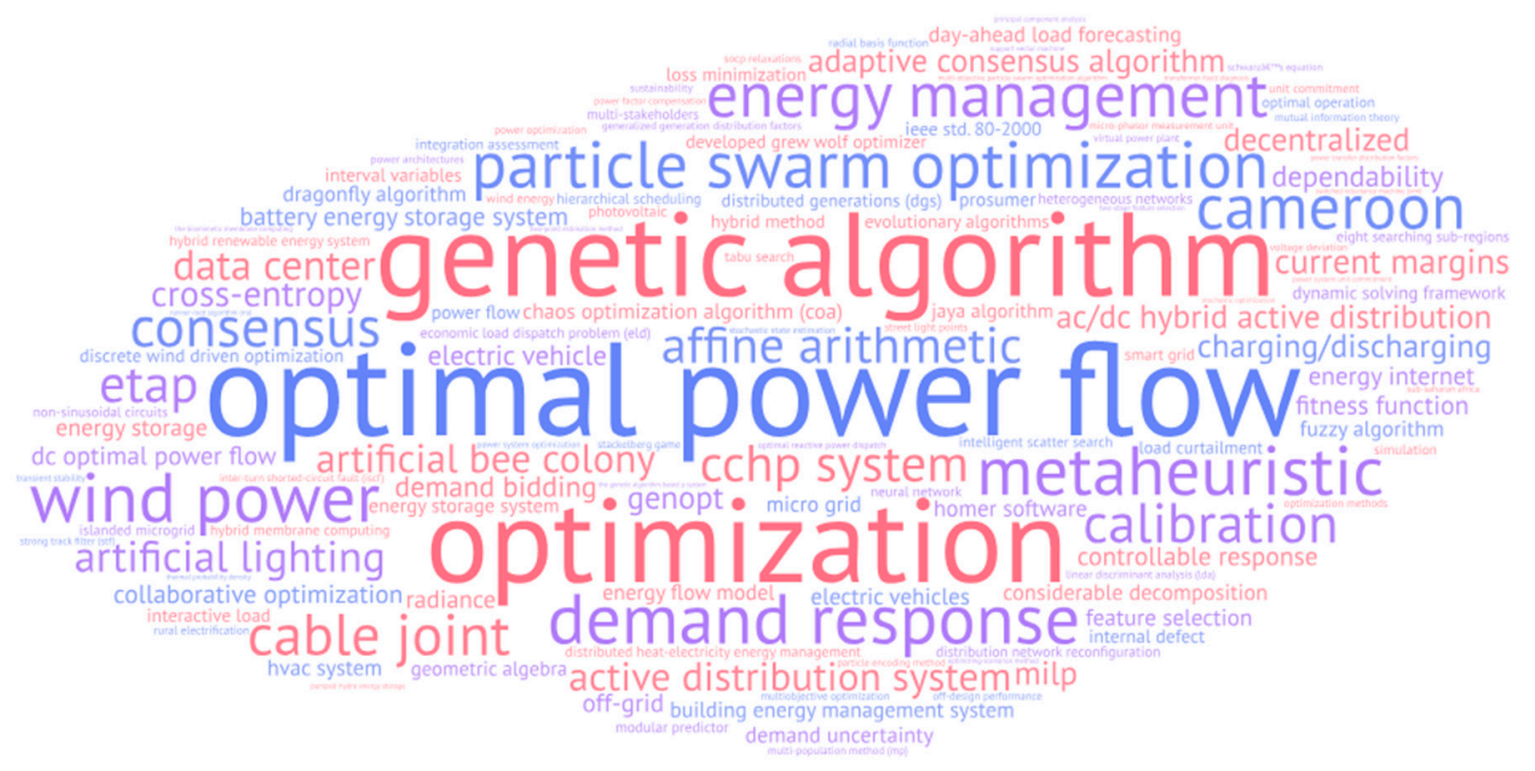

Figure 1. Cloud word of the author keywords related to the special issue. 


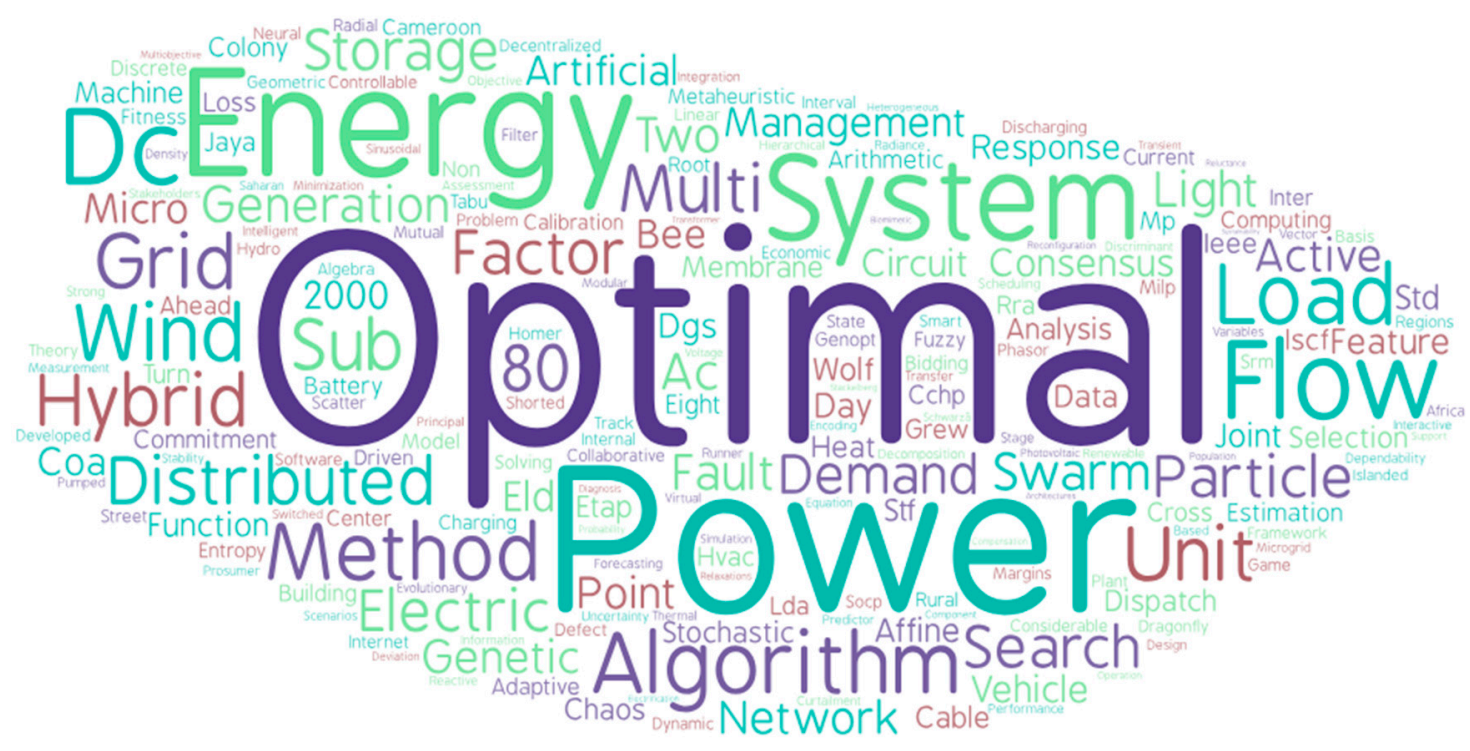

Figure 2. Cloud word for split author keywords related to the special issue.

\subsection{Analysis of Author Relationship}

Figure 3 shows a graph with the authors of this special issue. Each author is a node and a different color indicates their affiliation country. If an author collaborates with another one, then a link highlights the relationship between them. The larger the size of the node, the larger the H-index of this author. As expected, there is no relationship between authors of the different manuscripts, unless they are authors who have contributed to more than one, but they were exactly the same authors. What does attract attention is that there are at least nine papers with international collaboration, i.e., between authors from different countries, and two of them are collaborations between authors from at least three different countries.

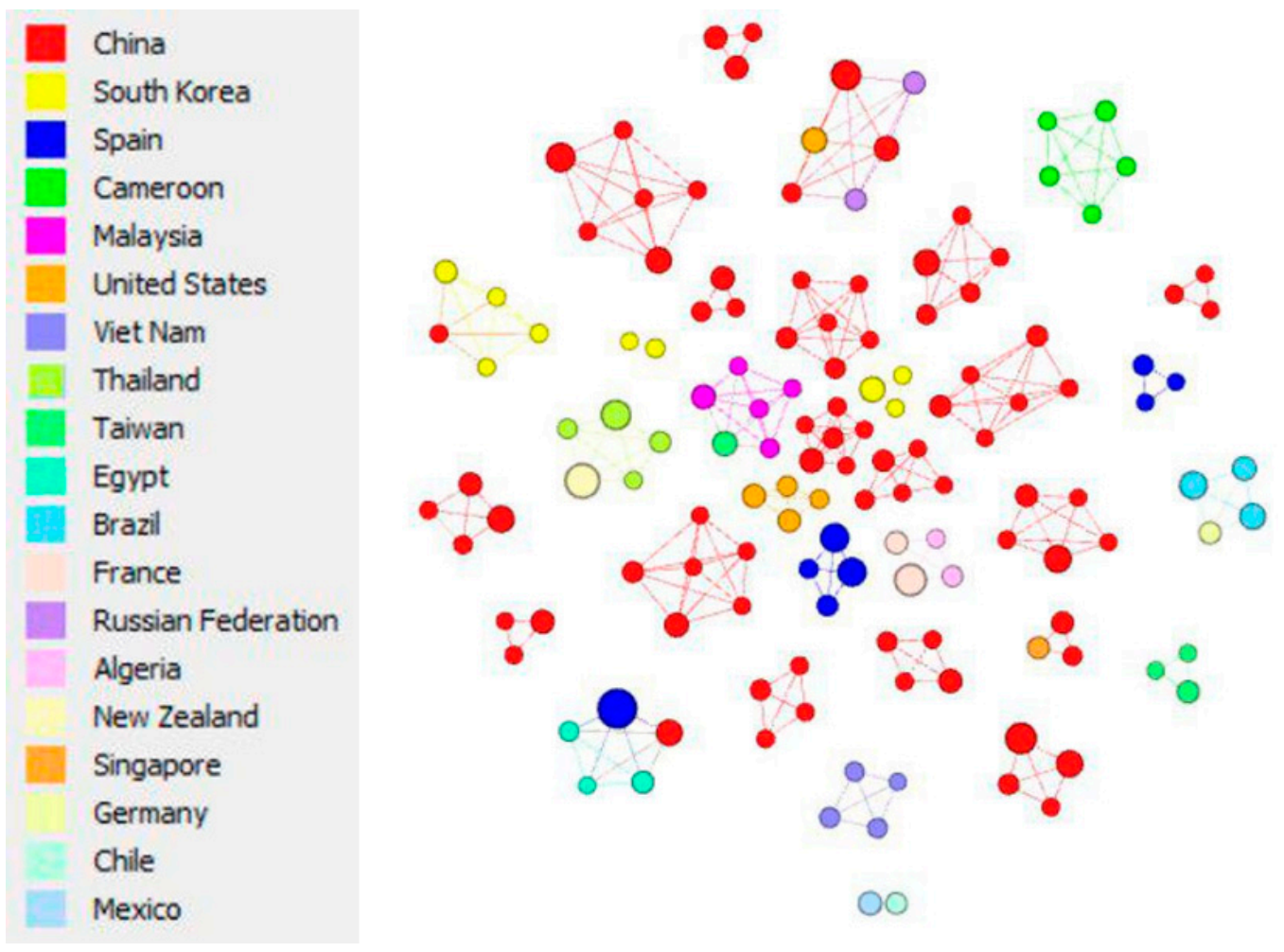

Figure 3. International interconnection between authors. 
Conflicts of Interest: The authors declare no conflict of interest

\section{References}

1. Leiva, J.; Carmona Pardo, R.; Aguado, J.A. Data Analytics-Based Multi-Objective Particle Swarm Optimization for Determination of Congestion Thresholds in LV Networks. Energies 2019, 12, 1295. [CrossRef]

2. Alcayde, A.; Baños, R.; Arrabal Campos, F.M.; Montoya, F.G. Optimization of the Contracted Electric Power by Means of Genetic Algorithms. Energies 2019, 12, 1270. [CrossRef]

3. Montoya, F.G.; Alcayde, A.; Arrabal Campos, F.M.; Baños, R. Quadrature Current Compensation in Non-Sinusoidal Circuits Using Geometric Algebra and Evolutionary Algorithms. Energies 2019, 12, 692. [CrossRef]

4. Chen, Z.; Han, X.; Fan, C.; Zheng, T.; Mei, S. A Two-Stage Feature Selection Method for Power System Transient Stability Status Prediction. Energies 2019, 12, 689. [CrossRef]

5. Xie, M.; Du, Y.; Cheng, P.; Wei, W.; Liu, M. A Cross-Entropy-Based Hybrid Membrane Computing Method for Power System Unit Commitment Problems. Energies 2019, 12, 486. [CrossRef]

6. Chen, S.; Chen, H.; Jiang, S. Optimal Decision-Making to Charge Electric Vehicles in Heterogeneous Networks: Stackelberg Game Approach. Energies 2019, 12, 325. [CrossRef]

7. Mao, T.; Zhang, X.; Zhou, B. Intelligent Energy Management Algorithms for EV-charging Scheduling with Consideration of Multiple EV Charging Modes. Energies 2019, 12, 265. [CrossRef]

8. Xiao, L.; Sun, H.; Zhang, L.; Niu, F.; Yu, L.; Ren, X. Applications of a Strong Track Filter and LDA for On-Line Identification of a Switched Reluctance Machine Stator Inter-Turn Shorted-Circuit Fault. Energies 2019, 12, 134. [CrossRef]

9. Viet Truong, A.; Ngoc Ton, T.; Thanh Nguyen, T.; Duong, T. Two States for Optimal Position and Capacity of Distributed Generators Considering Network Reconfiguration for Power Loss Minimization Based on Runner Root Algorithm. Energies 2019, 12, 106. [CrossRef]

10. Perng, J.W.; Kuo, Y.C.; Lu, S.P. Grounding System Cost Analysis Using Optimization Algorithms. Energies 2018, 11, 3484. [CrossRef]

11. Li, X.; Zhao, D.; Guo, B. Decentralized and Collaborative Scheduling Approach for Active Distribution Network with Multiple Virtual Power Plants. Energies 2018, 11, 3208. [CrossRef]

12. Cheng, W.; Cheng, R.; Shi, J.; Zhang, C.; Sun, G.; Hua, D. Interval Power Flow Analysis Considering Interval Output of Wind Farms through Affine Arithmetic and Optimizing-Scenarios Method. Energies 2018, 11, 3176. [CrossRef]

13. Chen, Y.; Xiang, J.; Li, Y. SOCP Relaxations of Optimal Power Flow Problem Considering Current Margins in Radial Networks. Energies 2018, 11, 3164. [CrossRef]

14. Li, J.J.; Shao, B.Z.; Li, J.H.; Ge, W.C.; Zhang, J.H.; Zhou, H.Y. Intelligent Regulation Method for a Controllable Load Used for Improving Wind Power Integration. Energies 2018, 11, 3085. [CrossRef]

15. Wu, J.; Li, K.; Sun, J.; Xie, L. A Novel Integrated Method to Diagnose Faults in Power Transformers. Energies 2018, 11, 3041. [CrossRef]

16. Ben Hmida, J.; Javad Morshed, M.; Lee, J.; Chambers, T. Hybrid Imperialist Competitive and Grey Wolf Algorithm to Solve Multiobjective Optimal Power Flow with Wind and Solar Units. Energies 2018, 11, 2891. [CrossRef]

17. Ye, C.; Miao, S.; Li, Y.; Li, C.; Li, L. Hierarchical Scheduling Scheme for AC/DC Hybrid Active Distribution Network Based on Multi-Stakeholders. Energies 2018, 11, 2830. [CrossRef]

18. Ferreira, J.; Callou, G.; Tutsch, D.; Maciel, P. PLDAD—An Algorihm to Reduce Data Center Energy Consumption. Energies 2018, 11, 2821. [CrossRef]

19. Kim, N.K.; Shim, M.H.; Won, D. Building Energy Management Strategy Using an HVAC System and Energy Storage System. Energies 2018, 11, 2690. [CrossRef]

20. Yimen, N.; Hamandjoda, O.; Meva'a, L.; Ndzana, B.; Nganhou, J. Analyzing of a photovoltaic/wind/biogas/ pumped-hydro off-grid hybrid system for rural electrification in Sub-Saharan Africa-Case study of Djoundé in Northern Cameroon. Energies 2018, 11, 2644. [CrossRef]

21. Yao, L.; Lim, W.; Tiang, S.; Tan, T.; Wong, C.; Pang, J. Demand bidding optimization for an aggregator with a Genetic Algorithm. Energies 2018, 11, 2498. [CrossRef] 
22. Lee, H.L.; Chun, Y.H. Using Piecewise Linearization Method to PCS Input/Output-Efficiency Curve for a Stand-Alone Microgrid Unit Commitment. Energies 2018, 11, 2468. [CrossRef]

23. Kuang, J.; Zhang, C.; Li, F.; Sun, B. Dynamic Optimization of Combined Cooling, Heating, and Power Systems with Energy Storage Units. Energies 2018, 11, 2288. [CrossRef]

24. Khunkitti, S.; Siritaratiwat, A.; Premrudeepreechacharn, S.; Chatthaworn, R.; Watson, N. A Hybrid DA-PSO Optimization Algorithm for Multiobjective Optimal Power Flow Problems. Energies 2018, 11, 2270. [CrossRef]

25. Dong, X.; Zhang, X.; Jiang, T. Adaptive Consensus Algorithm for Distributed Heat-Electricity Energy Management of an Islanded Microgrid. Energies 2018, 11, 2236. [CrossRef]

26. Gutierrez Alcaraz, G.; Hinojosa, V. Using Generalized Generation Distribution Factors in a MILP Model to Solve the Transmission-Constrained Unit Commitment Problem. Energies 2018, 11, 2232. [CrossRef]

27. Ogando Martínez, A.; López Gómez, J.; Febrero-Garrido, L. Maintenance Factor Identification in Outdoor Lighting Installations Using Simulation and Optimization Techniques. Energies 2018, 11, 2169. [CrossRef]

28. Sahli, Z.; Hamouda, A.; Bekrar, A.; Trentesaux, D. Reactive Power Dispatch Optimization with Voltage Profile Improvement Using an Efficient Hybrid Algorithm. Energies 2018, 11, 2134. [CrossRef]

29. Sun, Y.; Wang, Y.; Bai, L.; Hu, Y.; Sidorov, D.; Panasetsky, D. Parameter Estimation of Electromechanical Oscillation Based on a Constrained EKF with C\&I-PSO. Energies 2018, 11, 2059.

30. Yu, J.; Kim, C.H.; Wadood, A.; Khurshiad, T.; Rhee, S.B. A novel multi-population based chaotic JAYA algorithm with application in solving economic load dispatch problems. Energies 2018, 11, 1946. [CrossRef]

31. Wu, Z.; Du, X.; Gu, W.; Ling, P.; Liu, J.; Fang, C. Optimal Micro-PMU Placement Using Mutual Information Theory in Distribution Networks. Energies 2018, 11, 1917. [CrossRef]

32. Lin, L.; Xue, L.; Hu, Z.; Huang, N. Modular predictor for day-ahead load forecasting and feature selection for different hours. Energies 2018, 11, 1899. [CrossRef]

33. Liu, N.; Guo, B.; Liu, Z.; Wang, Y. Distributed Energy Sharing for PVT-HP Prosumers in Community Energy Internet: A Consensus Approach. Energies 2018, 11, 1891. [CrossRef]

34. Abdo, M.; Kamel, S.; Ebeed, M.; Yu, J.; Jurado, F. Solving Non-Smooth Optimal Power Flow Problems Using a Developed Grey Wolf Optimizer. Energies 2018, 11, 1692. [CrossRef]

35. Zhang, L.; LuoYang, X.; Le, Y.; Yang, F.; Gan, C.; Zhang, Y. A Thermal Probability Density-Based Method to Detect the Internal Defects of Power Cable Joints. Energies 2018, 11, 1674. [CrossRef]

36. Bravo Rodríguez, J.C.; del Pino López, J.C.; Cruz Romero, P. A Survey on Optimization Techniques Applied to Magnetic Field Mitigation in Power Systems. Energies 2019, 12, 1332. [CrossRef] 